\title{
FAKTOR-FAKTOR YANG BERHUBUNGAN DENGAN KEPEMILIKAN JAMBAN SEHAT KELUARGA DI DESA BUSUNG KECAMATAN TEUPAH TENGAH KABUPATEN SIMEULUE
}

\author{
Endang Maryanti*, Silvia Ramona, Linde Hernike \\ Program Studi Kesehatan Masyarakat, Institut Kesehatan Helvetia \\ *email: endangmaryanti58@gmail.com
}

\begin{abstract}
Abstrak
Jamban merupakan tempat yang digunakan untuk membuang kotoran manusia. Pembuatan jamban merupakan salah satu upaya manusia untuk menjaga kesehatan lingkungan sebagai tempat yang sehat. Berdasarkan hasil survei awal terhadap 10 rumah tangga di Desa Busung, Kecamatan Teupah Tengah, Kabupaten Simeuleu, terdapat 7 rumah tangga yang memiliki jamban yang tidak memenuhi syarat jamban sehat dan 3 rumah tangga memiliki jamban yang memenuhi syarat jamban sehat. Penelitian ini bertujuan untuk mengetahui faktor-faktor yang berhubungan dengan kepemilikan jamban sehat keluarga di Desa Busung Kecamatan Teupah Tengah Kabupaten Simeulue. Jenis penelitian yang digunakan adalah metode penelitian survey analitik dengan rancangan cross sectional. Populasi dalam penelitian ini adalah 177 rumah tangga di Desa Busung Kecamatan Teupah Tengah Kabupaten Simeuleu. Sampel penelitian sebanyak 64 keluarga, diambil dengan teknik proporsional random sampling. Data diperoleh dengan data primer berupa kuesioner. Analisis data dilakukan secara univariat dan bivariat menggunakan uji chi-square. menunjukkan bahwa ada hubungan antara pengetahuan $(p=0,021)$ pendidikan $(p=0,043)$ dan peran tenaga kesehatan $(p=$ 0,038) dengan kepemilikan jamban sehat di Desa Busung Kecamatan Teupah Tengah Kabupaten Simeulue.
\end{abstract}

\section{Kata Kunci: Pengetahuan, Pendidikan, Peran Petugas Kesehatan, Jamban Sehat}

\begin{abstract}
The latrine is a place that is used to remove feces or human waste. Making latrines is a human effort to maintain health by making the environment a healthy place. Based on the results of an initial survey of 10 households at Desa Busung, Teupah Tengah Sub District, Simeuleu District, 7 households had latrines that did not meet the requirements of healthy latrines and 3 households had latrines that met the requirements of healthy latrine. of this study was to determine the factors related to the ownership of the family's healthy latrines at Desa Busung, Teupah Tengah Sub District, Simeulue District in 2018. The design of this research is analytical survey research method with cross sectional design. The populations in this study were 177 households at Desa Busung, Teupah Tengah Sub District of Simeuleu District. The research sample was 64 families, taken by proportionate random sampling technique. The data obtained with primary data in the form of a questionnaire. Data analysis was performed in univariate and bivariate using chi-square test. showed that there was a relationship between knowledge $(p=0.021)$ of education $(p=0.043)$ and the role of health workers $(p=0.038)$ with the ownership of family healthy latrines at Desa Busung, Teupah Tengah Sub District of Simeuleu Districtk.
\end{abstract}

Keywords: Knowledge, education, the role of health workers, healthy latrines 


\section{PENDAHULUAN}

Pembangunan kesehatan adalah upaya yang dilaksanakan oleh semua komponen bangsa indonesia yang bertujuan untuk meningkatkan kesadaran, kemauan dan kemampuan hidup sehat bagi setiap orang agar terwujud derajat kesehatan masyarakat yang setinggi-tingginya, sebagai investasi bagi pembangunan sumber daya manusia yang produktif secara dan ekonomis, keberhasilan pembangunan kesehatan sangat ditentukan oleh kesinambungan antar upaya program dan sektor serta kesinambungan dengan upayaupaya yang telah dilaksanakan oleh periode sebelumnya. ${ }^{1}$

Kesehatan merupakan hak dasar manusia dan merupakan salah satu faktor yang sangat menentukan kualitas sumber daya manusia, oleh karena itu kesehatan perlu dipelihara dan ditingkatkan kualitasnya serta dilindungi dari ancaman yang merugikannya. Menurut Blum derajat kesehatan dipengaruhi olehbanyak faktor yaitu keturunan, pelayanan kesehatan, perilaku dan lingkungan. Faktor lingkungan dan perilaku sangat mempengaruhi derajat kesehatan.yang termasuk lingkungan adalah keadaan pemukiman dan perumahan, tempat kerja, sekolah dan tempat umum, air dan udara bersih,juga teknologi, pendidikan,sosial dan ekonomi. Sedangkan prilaku tergambar dalam kebiasaan sehari-hari seperti pola makan, kebersihan perorangan, gaya hidup dan prilaku terhadap upaya kesehatan. ${ }^{2}$

Pengelolaan jamban dipengaruhi oleh tingkat pengetahuan, sikap dan partisispasi seseorang terhadap penyediaan sarana dan prasarana. $\mathrm{Di}$ daerah perdesaan, dimana masyarakat yang belum mempunyai jamban keluarga yang masih membuang tinja di sembarang tempat, sedangkan masyarakat yang mempunyai jamban keluarga belum semuanya memenuhi syarat kesehatan. Hal ini disebabkan karena pengelolaan jamban keluarga belum dilakukan dengan baik. ${ }^{3}$ Menurut Peraturan Menkes RI No. 39 tahun 2016 tentang pedoman penyelenggaraan program indonesia sehat dengan pendekatan keluarga bahwa keluarga mempunyai akses menggunakan jamban sehat adalah jika keluarga tersebut memiliki akses dan menggunakan sarana untuk buang air besar berupa kloset leher angsa atau plengsengan. ${ }^{4}$ Jamban merupakan fasilitas pembuangan tinja yang efektif untuk memutuskan mata rantai penularan penyakit. Penggunaan jamban tidak hanya nyaman melainkan juga turut melindungi dan meningkatkan kesehatan keluarga dan masyarakat dengan bertambahnya jumlah penduduk yang tidak sebanding dengan area pemukiman yang ada, masalah pembuanga kotoran manusia menjadi meningkat, dilihat dari segi kesehatan masyarakat, masalah pembuangan kotoran manusia merupakan masalah pokok untuk sedini mungkin diatasi. ${ }^{5}$

Jamban keluarga merupakan sarana sanitasi dasar untuk menjaga kesehatan lingkungan dalam rangka meningkatkan derajat masyarakat. Masalah penyakit lingkungan pemukiman khususnya pada pembuangan tinja merupakan salah satu dari berbagai masalah kesehatan yang perlu mendapatkan prioritas. Penyediaan sarana pembuangan tinja terutama dalam pelaksanaan tidaklah mudah, karena menyangkut peran serta masyarakat yang biasanya sangat erat kaitannya dengan perilaku, tingkat ekonomi, kebudayaan dan pendidikan. ${ }^{6}$

Setiap anggota rumah tangga harus menggunakan jamban untuk buang air besar/buang air kecil penggunaan jamban akan bermanfaat untuk menjaga lingkungan tetap bersih, sehat, dan tidak berbau. Jamban mencegah pencemaran sumber air yang ada disekitarnya dan juga tidak mengundang datangnya lalat atau serangga yang dapat menjadi tempat penularan penyakit diare, kolera, disentri, typus, cacingan,dan lain-lain. Sebaiknya semua orang BAB di jamban yang memenuhi syarat dengan demikian wilayahnya terbebas dari ancaman penyakit-penyakit dengan $B A B$ di jamban banyak penyakit berbasis lingkungan yang dapat dicegah dengan penggunaan jamban yang memenuhi syarat kesehatan. ${ }^{6}$

Peraturan Pemerintah Nomor 66 Tahun 2014 tentang kesehatan lingkungan menyatakan bahwa kesehatan lingkungan adalah upaya pencegahan penyakit dan gangguan kesehatan dari faktor resiko lingkungan untuk mewujudkan kualitas lingkungan yang sehat baik dari aspek fisik, kimia, biologi maupun sosial kondisi dan kontrol dari kesehatan lingkungan berpotensial untuk mempengaruhi kesehatan. ${ }^{7}$

Menurut WHO Tahun 2011, lebih dari 2,6 milyar orang pada pedesaan dan perkotaan kini tidak memiliki akses terhadap sanitasi dasar. Hampir $70 \%$ masyarakat masih terbiasa $\mathrm{BAB}$ sembarangan dan Indonesia masih 
tertinggal dalam hal akses sanitasi, indonesia sebagai negara kedua terbanyak ditemukan masyarakat buang air besar di area terbuka, yaitu India (58)\%, Indonesia $(12,9) \%$, Cina $(4,5) \%$, Ethiopia $(4,4) \%$, Pakistan $(4,3) \%$, Nigeria (3)\%, Sudan $(1,5) \%$, Nepal $(1,3) \%$, BraziL $(1,2) \%$ dan Nigeria $(1,1) \%{ }^{8}$

Survei Sosial Ekonomi Nasional Indonesia (Susenas) tahun 2015 mengenai persentase rumah tangga yang memiliki akses terhadap sanitasi layak, menunjukan bahwa persentase rumah tangga yang memiliki akses terhadap sanitasi layak hanya berkisar $62,14 \%$. Provinsi dengan persentase rumah tangga yang memiliki akses sanitasi layak yang tertinggi yaitu DKI Jakarta sebesar $82,28 \%$, Yogyakarta sebesar $86,31 \%$, dan Bali sebesar $85,46 \%$. Sedangkan provinsi dengan persentase rumah tangga yang memiliki akses terhadap sanitasi layak terendah adalah Nusa Tenggara Timur sebesar 23,90\%, Papua sebesar 28,04\% dan Kalimantan Tengah sebesar $35,88 \% .{ }^{9}$

Berdasarkan Data Badan Pusat Statistik Provinsi Aceh (BPS) tahun 2017 akses sanitasi di daerah perdesaan masih sangat rendah $24,7 \%$ atau salah satu dari empat rumah tangga yang tinggal di daerah perdesaan di Provinsi Aceh tidak memiliki jamban. Meskipun kondisi di daerah perkotaan jauh lebih baik, Namun masih ada 5,6\% rumah tangga yang tinggal di perkotaan yang tidak memiliki jamban. Tidak heran apabila Provinsi Aceh merupakan Provinsi dengan insiden diare tertinggi, tiga Kabupaten dengan insiden diare tertinggi adalah Kabupaten Pidie Jaya (17,9\%), Aceh Tenggara (17,3\%) dan Aceh Timur $(16,9 \%) .{ }^{10}$

Berdasarkan Profil Dinas Kesehatan Kabupaten Simeulue adapun jumlah KK dengan tempat $B A B$ jamban yang memiliki sanitasi yang layak sebanyak 28.753 dengan persentase jamban yang memenuhi syarat sehat sebesar $32.3 \%$ dan selebihnya tidak memenuhi syarat dan masih menggunakan sungai, pantai, kebun/semak-semak dan tempat lain sebagai tempat pembuangan kotoran. Pada tahun 2015 penduduk dengan akses sanitasi jamban yang layak tertinggi berada di Kecamatan Simeulue Barat yaitu sebanyak 4805 penduduk atau sebesar $71,2 \%$ kemudian disusul kecmatan simeulue cut sebanyak 1879 penduduk atau sebesar $59.7 \%$ dan sanitasi jamban terendah berada di kecamatan sanggiran sebanyak 200 penduduk atau sebesar $5,0 \%{ }^{11}$

Ketersediaan jamban keluarga sehat merupakan salah satu wujud perilaku sehat.Menurut Green (1980) dalam buku Notoadmojdo, perilaku masyarakat dipengaruhi oleh 3 faktor yaitu faktor yaitu faktor predisposisi merupakan faktor dasar motivasi untuk bertindak meliputi : pengetahuan, sikap, keyakinan, persepsi, ekonomi, dan pendidikan masyarakat. Faktor pemungkin merupakan faktor yang memungkinkan suatu untuk melakukan suatu tindakan.Meliputi : ketersediaan sarana SDM dan pelayanan kesehatan. dan faktor penguat merupakan yang memperkuat perubahan prilaku seseorang yang meliputi dukung an keluarga, petugas kesehatan. perilaku kepala keluarga berkaitan dengan faktor predisposisi dan faktor penguat yaitu tingkat pendidikan, tingkat pengetahuan, dan peran petugas kesehatan. $^{12}$

Penyakit yang terkait dengan masalah jamban di UPTD Puskesmas Teupah Tengah Kabupaten Simeulue adalah Diare sebesar $53,1 \%$, Typus sebesar $42,1 \%$, Disentri sebesar $23,4 \%$, Cacingan sebesar $21,1 \%$, dan Gatalgatal sebesar $18,3 \%$.

Berdasarkan survei awal yang dilakukan peneliti di Desa Busung Kecamatan Teupah Tengah Kabupaten Simeulue terhadap 10 kepala Keluarga (KK) didapatkan hasil bahwa 7 Kepala Keluarga(KK) memiliki jamban yang tidak memenuhi syarat jamban sehat dan 3 Kepala Keluarga (KK) memiliki jamban yang memenuhi syarat jamban sehat. Berdasarkan data profil Desa Busung tahun 2015-2018 jumlah penduduk 630 jiwa dan 177 KK yang mayoritas penduduknya beragama islam $100 \%$ serta bermata pencaharian sebagai petani, nelayan, perkebunan, pedagang, dan sebagian kecilnya menjadi pegawai dikantor pemerintahan dan swasta. dari $177 \mathrm{KK}$ Penduduk yang menggunakan jamban leher angsa sebanyak 56 Kepala Keluarga (32\%) belum memenuhi syarat seperti jamban sehat, yang menggunakan jamban plengsengan sebanyak 47Kepala Keluarga (27\%) dan yang menggunakan jamban empang sebanyak 74 Kepala Keluarga $(42 \%){ }^{13}$

Berdasarkan uraian di atas dapat disimpulkan bahwa masih sangat rendah masyarakat yang memiliki jamban sehat keluarga sehingga peneliti ingin melakukan penelitian dengan judul "Faktor-faktor yang berhubungan dengan kepemilikan jamban 
sehat keluarga di Desa Busung Kecamatan Teupah Tengah Kabupaten Simeulue, Tujuan dari penelitian ini adalah untuk mengetahui faktor-faktor yang berhubungan dengan kepemilikan jamban sehat di Desa Busung Kecamatan Teupah Tengah Kabupaten Simeulue.

\section{METODE PENELITIAN}

Jenis penelitian ini adalah penelitian analitikdengan menggunakan desain penelitian cross sectional karena pengambilan data semua variabel dilakukan bersamaan. Penelitian ini akan dilakukan di Desa Busung Kecamatan Teupah Tengah Kabupaten Simeulue. Pemilihan Lokasi ini karena masih ada warga yang menggunakan jamban yang tidak memenuhi syarat kesehatan di Desa Busung Kecamatan Teupah Tengah Kabupaten Simeulue. Populasi dalam

\section{.HASIL PENELITIAN}

Karakteristik Responden

Tabel 1. Distribusi Frekuensi Berdasarkan Karakteristik Responden

\begin{tabular}{ccc}
\hline Karakteristik & \multicolumn{2}{c}{ Jumlah } \\
\cline { 2 - 3 } Kelompok Umur & Frekuensi (f) & Persentase (\%) \\
32-38 tahun & 12 & \\
39-45 tahun & 13 & 18,7 \\
46-52 tahun & 12 & 20,3 \\
53-59 tahun & 10 & 18,7 \\
60-66 tahun & 12 & 15,6 \\
67-73 tahun & 5 & 18,7 \\
Jenis Kelamin & 15 & 7,8 \\
Perempuan & 19 & 23,4 \\
Laki-laki & & 76,6 \\
\hline Agama & 63 & \\
Islam & 1 & 94,1 \\
Kristen & & 1,6 \\
\hline Jenis Pekerjaan & 20 & 31,1 \\
Petani & 19 & 29,7 \\
Wiraswata & 12 & 18,8 \\
Nelayan & 3 & 4,7 \\
PNS & 7 & 10,9 \\
IRT & 3 & 4,7 \\
\hline Perawat & &
\end{tabular}

penelitian ini adalah seluruh kepala keluarga (KK) di Desa Busung Kecamatan Teupah Tengah Kabupaten Simeulue yang berjumlah 177 Kepala Kelurga. Sampel penelitian menggunakan rumus slovin didapatkan jumlah sample sebanyak 64 sampel.

Analisis data yang digunakan dalam penelitian ini adalah analisis univariat yaitu analisis yang digunakan untuk masing-masing variabel yang menggambarkan distribusi frekuensi masing-masing variabel, baik variabel bebas(independent)maupun variabel terikat (dependent). Analisis bivariat yaitu analisis yang dilakukan untuk membuktikan adanya hubungan yang signifikan antara variabel bebas dengan variabel terikat melalui tabulasi silang data analisis dengan uji statistik chi-square 
Analisis Univariat

Tabel 2. Distribusi Frekuensi Pengetahuan, Pendidikan, Peran petugas Kesehatan dan Kepemilikan Jamban Sehat

\begin{tabular}{|c|c|c|}
\hline Variabel & Frekuensi (f) & Persentase (\%) \\
\hline \multicolumn{3}{|l|}{ Pengetahuan } \\
\hline Baik & 7 & 10,9 \\
\hline Cukup & 18 & 28,1 \\
\hline Kurang & 39 & 60,9 \\
\hline \multicolumn{3}{|l|}{ Pendidikan } \\
\hline Dasar & 40 & 62,5 \\
\hline Menengah & $\begin{array}{c}16 \\
8\end{array}$ & 25,0 \\
\hline \multicolumn{3}{|l|}{ Tinggi } \\
\hline \multirow{2}{*}{\multicolumn{3}{|c|}{ Peran Petugas Kesehatan }} \\
\hline & 41 & 64,1 \\
\hline Ada Peran Petugas Kesehatan & 23 & 35,9 \\
\hline \multicolumn{3}{|l|}{$\begin{array}{l}\text { Kepemilikan Jamban Sehat } \\
\text { Tidak Memiliki Jamban Sehat }\end{array}$} \\
\hline Tidak Memiliki Jamban Sehat & 44 & 68,8 \\
\hline Memiliki Jamban Sehat & 20 & 31,3 \\
\hline
\end{tabular}

Berdasarkan Tabel 2. Pada variabel pengetahuan menunjukkan bahwa 7 responden $(10,9 \%)$ memiliki pengetahuan yang baik, sebanyak 18 responden $(28,1 \%)$ memiliki pengetahuan yang cukup dan sebanyak 39 responden $(60,9 \%)$ memiliki pengetahuan kurang baik.pendidikan responden di Desa Busung Kecamatan Teupah Tengah Kabupaten Simeulue tahun 2018 Pendidikan Dasar sebanyak 40 orang $(62,5 \%)$, Menengah sebanyak 16 orang Analisis Bivariat

Tabel 3. Tabulasi SilangFaktor-faktor yang Berhubungan dengan Jamban Sehat Keluarga

\begin{tabular}{|c|c|c|c|c|c|c|c|}
\hline \multirow{3}{*}{ Variabel } & \multicolumn{4}{|c|}{ Kepemilikan Jamban Sehat } & & & \multirow{3}{*}{$P$ Value } \\
\hline & \multicolumn{2}{|c|}{$\begin{array}{l}\text { Tidak Memiliki } \\
\text { Jamban Sehat }\end{array}$} & \multicolumn{2}{|c|}{$\begin{array}{c}\text { Memiliki } \\
\text { Jamban Sehat }\end{array}$} & \multicolumn{2}{|c|}{ Total } & \\
\hline & $f$ & $\%$ & $f$ & $\%$ & $f$ & $\%$ & \\
\hline \multicolumn{8}{|l|}{ Pengetahuan } \\
\hline Kurang & 23 & 35,9 & 16 & 25,0 & 39 & 60,9 & \multirow{3}{*}{0,021} \\
\hline Cukup & 17 & 26,6 & 1 & 1,6 & 18 & 28,1 & \\
\hline Baik & 4 & 6,3 & 3 & 4,7 & 7 & 11,0 & \\
\hline \multicolumn{8}{|l|}{ Pendidikan } \\
\hline Dasar & 23 & 35,1 & 17 & 26,6 & 40 & 62,5 & \multirow{3}{*}{0,043} \\
\hline Menengah & 14 & 21,9 & 2 & 3,1 & 16 & 25,0 & \\
\hline Tinggi & 7 & 10,9 & 1 & 1,6 & 8 & 12,5 & \\
\hline \multicolumn{8}{|l|}{ Peran Petugas Kesehatan } \\
\hline TidakAdaPeranPetugas & 24 & 37,5 & 17 & 26,6 & 41 & 64,1 & \multirow{2}{*}{0,038} \\
\hline Ada Peran Petugas & 20 & 31,3 & 3 & 4,7 & 23 & 35,9 & \\
\hline
\end{tabular}

Berdasarkan Tabel 3.dapat dilihat bahwa dari 39 responden dengan pengetahuan kurang tidak memiliki jamban sehat sebanyak $23(35,9$ $\%)$ responden dan memiliki jamban sehat sebanyak $16(25,0 \%)$ responden. Dari 18 responden dengan pengetahuan cukup tidak memiliki jamban sehat sebanyak $17(26,6 \%)$ responden dan memiliki jamban sehat sebanyak $1(1,6 \%)$ responden. Kemudian dari 7 responden dengan pengetahuan baik tidak memiliki jamban sehat sebanyak 4 (6,3\%)
$(25,0 \%)$ dan Pendidikan tinggi sebanyak 8 orang (12,5\%).Pada variabel Peran petugas kesehatan menunjukkan hasi sebanyak 41 responden $(64,1 \%)$ menyatakan tidak ada peran petugas kesehatan, dan sebanyak 23responden $(35,9 \%)$ menyatakan ada peran petugas kesehatan. Pada variabel Observasi jamban sehat menunjukkan haisl sebanyak 44 responden $(68,8 \%)$ tidak memiliki jamban sehat, dan sebanyak 20responden (31,3\%) memiliki jamban sehat.

\section{s.}


sehatsebanyak 17 (26,6\%) responden. Dari 16 responden dengan pendidikan menengah tidak memiliki jamban

sehat sebanyak $14(21,9 \%)$ responden dan Memiliki jamban sehat $2(3,1 \%)$ responden. Kemudian dari 8 responden dengan pendidikan tinggi tidak memiliki jamban sehat sebanyak 7 (10,9\%) responden dan Memiliki jamban sehat sebanyak $1(1,6 \%)$ responden. Hasil uji chi squaremenunjukkan bahwa terdapat nilai $p=0,043<0,05$, artinya ada hubungan antara pendidikan dengan kepemilikan jamban keluarga di Desa Busung Kecamatan Teupah Tengah Kabupaten Simeulue.

Dari variabel peran petugas kesehatan dapat dilihat bahwa dari 41 responden dengan Peran petugas kesehatan Tidak Memiliki jamban sehat sebanyak 24 (37,5\%) responden dan Memiliki jamban sehat sebanyak 17 (26,6\%) responden. Dari 23 responden dengan Peran petugas kesehatan tidak memiliki jamban sehat sebanyak 20 (31,3 $\%)$ responden dan Memiliki jamban sehat sebanyak $3(4,7 \%)$ responden. Hasil uji chi squaremenunjukkan bahwa terdapat nilai $\mathrm{p}=$ $0,038<0,05$, artinya ada hubungan antara Peran petugas kesehatan dengan kepemilikan jamban keluarga

\section{PEMBAHASAN}

\section{Hubungan Pengetahuan Responden dengan Kepemilikan Jamban Sehat Keluarga}

Berdasarkan data dari tabel 4.3 Hasil uji chi square menunjukkan bahwa terdapat nilai $p=0,021<0,05$, artinya ada hubungan antara pengetahuan dengan kepemilikan jamban keluarga di Desa Busung Kecamatan Teupah Tengah Kabupaten Simeulue.

Penelitian ini sejalan dengan penelitian yang dilakukan oleh Pirmansyah dengan judul hubungan antara pengetahuan masyarakat dan peran petugas kesehatan dengan sanitasi jamban di Wilayah Kerja Puskesmas Batang Asai Kabupaten Sarolangun Tahun 2013 disimpulkan bahwa ada hubungan antara peran petugas kesehatan dengan sanitasi jamban keluarga di Wilayah Kerja Puskesmas Batang Asai Kabupaten Sarolangun, ada hubungan antara pengetahuan dengan sanitasi jamban keluarga di Wilayah Kerja Puskesmas Batang Asai Kabupaten
Sarolangun, 60,2\% responden memiliki sanitasi jamban keluarga yag tidak memenuhi syarat, $54,2 \%$ responden memiliki pengetahuan kurang baik, 57,8\% responden mengatakan peran petugas kesehatan kurang baik. $^{14}$

Penelitian ini sejalan dengan penelitian yang dilakukan oleh Widyastutik dengan judul Faktor yang Berhubungan Dengan Kepemilikan Jamban Sehat Di Desa Malikian Kalimantan Barat Tahun 2017 menunjukkan hasil pengetahuan yang baikhanya $65 \%$ responden yang memiliki jamban. Sebaliknya, dari responden yang tidak memiliki jamban, terdapat $91,7 \%$ responden yang baik pengetahuannya. Hasil uji statistik dengan menggunakan uji Chi-square dinyatakan bahwa terdapat hubungan yang bermakna antara pengetahuan baik dengan kepemilikan jamban sehat dengan $p$ value $=0,037$, artinya ada hubungan antara pengetahuan dengan kepemilikan jamban sehat. ${ }^{15}$

Penelitian ini sejalan dengan penelitian yang dilakukan oleh Novitry dengan judul Determinan Kepemilikan Jamban Sehat di Desa Sukomulyo Martapura Palembang Tahun 2017dari penelitian tersebut diperoleh hasil dari 87 responden yang berpengetahuan baik dan memiliki jamban $(66,7 \%)$ dan yang tidak memiliki jamban (33,3\%). Sedangkan responden dengan pengetahuan yang kurang baik, yang memiliki jamban $(33,4 \%)$ dan yang tidak memiliki jamban (66,6\%). Dari hasil analisa statistik dengan menggunakan uji chi squarediperoleh $(p<0,05)$, artinya ada hubungan yang bermakna antara pengetahuandengan kepemilikan jamban keluarga. $^{16}$

Pengetahuan adalah merupakan hasil tahu dan dapat terjadi setelah orang melakukan penginderaan terhadap objek tertentu. Penginderaan terjadi melalui panca indera manusia yaitu:indera penglihatan, pendengangaran, penciuman rasa dan raba. Sebagian besar pengetahuan manusia diperoleh melalui penglihatan rasa dan raba.Sebagian besar pengetahuan manusia diperoleh melalui penglihatan dan pendengaran.Pengetahuan merupakan dasar untuk terbentuknya sikap dan tindakan seseorang. ${ }^{17}$ 
Pengetahuan yang tercakup dalam domain kognitif mempunyai 6 tingkatan, meliputi tahu (know) diartikan sebagai mengingat suatu materi yang telah dipelajari sebelumnya, memahami (comprehession) diartikan sebagai suatu kemampuan untuk menjelaskan secara benar tentang objek yang diketahui, dan dapat menginterprestasikan materi tersebut secara benar, aplikasi (application) merupakan kemampuan untuk menggunakan materi yang telah dipelajari pada situasi atau kondisi real. Analisis (analysis) adalah suatu komponen untuk menjabarkan materi atau suatu objek ke dalam komponen-komponen, tetapi masih di dalam suatu struktur organisasi dan masih ada kaitannya satu sama lain, sintesis (synthesis) menunjukkan kepada suatu kemampuan untuk menciptakan atau menghubungkan bagianbagian di dalam suatu bentuk keseluruhan yang baru dan evaluasi (evaluation) berkaitan dengan kemampuan untuk melakukan penilaian terhadap suatu materi atau objek. ${ }^{18}$

Pengetahuan tentang jamban diperlukan sebagai dasar membentuk prilaku kepemilikan jamban. Pengetahuan masyarakat yang baik tentang jamban akan memengaruhi mereka dalam kepeilikan jamban. Menurut pendapat H.L Blum yang dikutip dalam buku Notoadmodjo, pengetahuan menyumbangkan peran dalam menetukan pengambil keputusan untuk melaksankan kepemilikan jamban.Semakin tinggi tingkat pengetahuan tentang kepemiikan jamban, maka semakin meningkat pula perannya sebagai pengambil keputusan. ${ }^{17}$

Menurut asumsi peneliti, pengetahuan responden dengan kepemilikan jamban keluarga di Desa Busung Kecamatan Teupah Tengah Kabupaten Simeulue masih kurang. Diharapkan peran petugas kesehatan lebih aktif lagi dalam mempromosikan syarat-syarat jamban sehat dan bagi responden untuk mencari informasi karena banyak manfaat dari penggunaan jamban sehat ini seperti terhindar dari penyakit, tidak mencemari sumber air bersih dan tanah dan lingkungan sekitar. Dengan baiknya pengetahuan masyarakat maka semakin baik untuk memahami dan mampu melaksanakan upaya pengelolaan jamban keluarga, baik dalam pemeliharaan atau perbaikan jamban jika rusak atau tersumbat serta menjaga kebersihan jamban keluarga dari berbagai kotoran sehingga lingkungan tempat tinggal bersih dan sehat dan dapat mencegah terjadinya pencemaran lingkungan.

\section{Hubungan Pendidikan Responden dengan Kepemilikan Jamban Sehat Keluarga}

Hasil uji chi squaremenunjukkan bahwa terdapat nilai $p=0,043<0,05$, artinya ada hubungan antara pendidikan dengan kepemilikan jamban keluarga di Desa Busung Kecamatan Teupah Tengah Kabupaten Simeulue.

Penelitan ini sejalan dengan penelitian yang dilakukan oleh Novianti dengan judul Faktor yang Berhubungan dengan Kepemilikan Jamban Keluarga di Desa Aek Goti Kecamatan Silang Kitang Kabupaten Labuhanbatu Selatan Tahun 2017 disimpulkan bahwa ada hubungan yang signifikan antara pendidikan dengan kepemilika jamban keluarga $(p=0,000)$. Hal ini dikarenakan persentase responden dengan pendidikan tinggi yang memilki jamban sebesar $83,3 \%$, sedangkan persentase responden dengan pendidikan rendah memiliki jamban sebesar $61,6 \%$. Sehingga dapat disimpulkan bahwa pendidikan berpengaruh terhadap kepemilikan jamban. ${ }^{18}$

Penelitian ini sejalan dengan penelitian Dharmadengan judul Faktor-Faktor yang Berhubungan Dengan Rendahnya Kepemilikan Jamban Keluarga di Desa Sei Musam Kendit Kecamatan Bahorok Kabupaten Langkat Tahun 2014 dapat dilihat bahwa dari 87 responden yang pendidikan tidak sekolah (100\%) tidak memiliki jamban. Responden dengan pendidikan SD yang memiliki jamban $(37,7 \%)$ dan yang tidak memiliki jamban (62,3\%). Responden dengan pendidikan SMP yang memiliki jamban $(56,0 \%)$ dan yang tidak memiliki jamban $(44,0 \%)$. Responden dengan pendidikan SMA yang memiliki jamban $(66,6 \%)$ dan yang tidak memiliki jamban (33,4\%) sedangkan responden dengan pendidikan Akademi/PT yang memiliki jamban (100\%). Dari hasil analisis statistik diperoleh $(\mathrm{p}<0,05)$, artinya ada hubungan yang bermakna antara pendidikan dengan kepemilikan jamban keluarga. ${ }^{19}$

Penelitian ini sejalan dengan penelitian yang dilakukan oleh Putra Ganda Sunarryo dengan judul Faktor-Faktor yang Berhubungan Dengan Kepemilikan Jamban Sehat Keluarga 
di Desa Napalakura Kecamatan Napabalano Kabupaten Muna Tahun 2016 hasil uji chi square menunjukan nilai $P$ value $0,008<0,05$ artinya ada hubungan yang bermakna antara tingkat pendidikan dengan kepemilikan jamban keluarga. ${ }^{20}$

Pendidikan berarti bimbingan yang diberikan seorang kepada perkembangan orang lain menuju kearah cita-cita tertentu. Pendidikan diperlukan untuk mendapatkan informasi sehingga makin banyak pula pengetahuan yang dimiliki sebaliknya, Pendidikan yang kurang akan menghambat sikap seseorang terhadap nilai-nilai yang diperlukan. ${ }^{21}$

Menurut asumsi peneliti, pendidikan sangat berpengaruh dalam menentukan sebuah pilihan. Semakin tinggi pendidikan seseorang maka semakin baik pula pengetahuan yang dimiliki. Hasil penelitian yang saya lakukan bahwa mayoritas masyarakat berpendidikan rendah,sehingga untuk pemilihan jamban sehat masih kurang.Jamban yang digunakan masyarakat masih ada yang menggunakan WC cemplung. Adapun jamban yang digunakan tidak memenuhi syarat seperti jarak antara jamban dengan sumber air bersih kurang dari $10 \mathrm{~m}$, sedangkan syarat jamban sehat harus memiliki jarak yang lebih dari 10 m. Jika kejadian ini berlangsung lama maka dapat mencemari sumber air bersih dan mencemari tanah serta mengganggu estetika lingkungan.

\section{Hubungan Peran Petugas Kesehatan dengan Kepemilikan Jamban Sehat Keluarga}

Hasil uji chi squaremenunjukkan bahwa terdapat nilai $p=0,038<0,05$, artinya ada hubungan antara Peran petugas kesehatan dengan kepemilikan jamban keluarga di Desa Busung Kecamatan Teupah Tengah Kabupaten Simeulue.

Penelitian ini sejalan dengan penelitian yang dilakukandenganolehJoseph dengan judul Faktor-Faktor yang Berhubungan Dengan Tersedianya Jamban Keluarga Sehat di Desa Tompaso Dua Kecamatan Tompaso Barat Kabupaten Minahasa Tahun 2018 yang menunjukkan hasil $p$-value sebesar 0,005 $(<0,05)$, maka dapat disimpulkan bahwa terdapat hubungan antara peran petugas kesehatan dengan kepemilikan jamban sehat. $^{22}$
Penelitian ini sejalan dengan penelitian yang dilakukan oleh Elsa dengan judul Analisis Faktor yang Berhubungan Dengan Rendahnya Kepemilikan Jamban di Desa Baru Semerah Kecamatan Setinjau Laut Kabupaten Kerinci Tahun 2016 didapatkan hasil penelitian dari 56 responden yang menyatakan peran petugas kesehatan kurang baik sebanyak $85,7 \%$ tidak memiliki jamban dan hanya $14,3 \%$ yang memiliki jamban. Dari hasil statistik uji chisquarediperoleh nilai $\mathrm{P}$ Value $0,01(<0,05)$, artinya ada hubungan yang bermakna antara peran petugas kesehatan dengan kepemilikan jamban. ${ }^{23}$

Penelitian ini sejalan dengan penelitian yang dilakukan olehHelenita Saliani dengan judul Faktor-Faktor yang Berhubungan Dengan Praktek Buang Air Besar Masyarakat di Desa Garuga Kecamatan Mantoh Kabupaten Banggai Provinsi Sulawesi Tengah Tahun 2016 yang menunjukan hasil $P$ Value $0,000<0,05$ yang artinya terdapat hubungan yang signifikan antara peran petugas kesehatan dengan praktek buang air besar masyarakat. ${ }^{24}$

Untuk berhasilnya suatu program kesehatan memerlukan dukungan dari berbagai pihak terutama petugas kesehatan.Kunci pada pengembangan petugas kesehatan adalah keterbukaan dan komunikasi yang timbal balik yang horizontal maupun vertikal. Untuk meningkatan pengetahuan masyarakat petugas kesehatan harus memberikan penyuluhan kepada masyarakat tentang pemanfaatan jamban yang tidak sehat dan dampak negatif dari penggunaan jamban yang tidak sehat dan dampak negarif dari penggunaan jamban yang tidak sehat.

Menurut asumsi peneliti bahwa Peran Petugas Kesehatan dengan Kepemilikan Jamban Keluarga di Desa Busung Kecamatan Teupah Tengah Kabupaten Simeulue masih kurang, hal ini sangat berpengaruh dalam pemilihan jamban sehat. Kurangnya sosialisasi dari petugas kesehatan disertai dengan pengetahuan masyarakat yang masih rendah mengakibatkan banyak masyarakat tidak memiliki jamban sehat.

\section{KESIMPULAN}

Berdasarkan menunjukanbahwa

$$
\begin{aligned}
& \text { hasil } \\
& \text { ada }
\end{aligned}
$$

penelitian hubungan 
pengetahuan, pendidikan, peran petugas kesehatan dengan kepemilikan jamban sehat keluarga di Desa Busung Kecamatan Teupah Tengah Kabupaten Simeulue.

\section{SARAN}

Saran yang disampaikan penulis diharapkan pengetahuan masyarakat semakin meningkat dengan adanya kerjasama antara masyarakat dengan petugas kesehatan dan lintas sektor terkait dengan memberikan penyuluhan tentang manfaat kepemilikan jamban keluarga yang sehat kepada masyarakat yang belum memenuhi syarat jambansehat di Desa Busung Kecamatan Teupah Tengah Kabupaten Simeulue, sehingga kesadaran masyarakat untuk memilki jamban sehat lebih tinggi.Diharapkan peran petugas kesehatan lebih aktif lagi dalam memotivasi masyarakat tentang pentingnya jamban keluarga dan sanitasi jamban keluarga yang memenuhi syarat kesehatan di Desa Busung Kecamatan Teupah Tengah Kabupaten Simeulue.

\section{DAFTAR PUSTAKA}

1. Kementerian Kesehatan Indonesia. Keputusan Menteri Kesehatan Republik Indonesia Nomor HK.02.02/Menkes/52/2015 Tentang Rencana Strategis Kementerian Kesehatan Tahun 2015-2019. 2015;

2. Chandra B. IImu Kesehatan Masyarakat dalam Konteks Kesehatan Lingkungan. Jakarta: EGC; 2012.

3. Azrul A. Pengantar Administrasi Kesehatan. Jakarta: Binarupa Aksara; 2006.

4. Kementerian Kesehatan Indonesia. Peraturan menteri kesehatan Republik indonesia Nomor 39 Tahun 2016 Tentang Pedoman Penyelenggaraan Program Indonesia Sehat dengan Pendekatan Keluarga. 2016;

5. Kementerian Kesehatan Indonesia. Keputusan Menteri Kesehatan Republik Indonesia Nomor 852. 2009;1-14.

6. Proverawati A, Rahmawati E. Perilaku Hidup Bersih dan Sehat. Yogyakarta: Nuha Medika; 2016.

7. Kementrian Kesehatan RI. Peraturan Pemerintah Nomor 66 Tahun 2014 tentang kesehatan lingkungan. 2014;

8. World Health Organization (WHO). Progress on sanitasion and drinkingwater. Ganeva: International Encyclopedia of Public Health; 2011.
9. Kementerian Kesehatan Indonesia. Dinas Kesehatan Republik Indonesia. Data Kesehat Nas. 2015;

10. Data Badan Pusat Statistik Provinsi Aceh Tahun 2017. 2017.

11. Profil Kesehatan Kabupaten Bangkalan Tahun 2015. 2015.

12. Arikunto S. Prosedur penelitian: Suatu pendekatan praktik. Jakarta: Rineka Cipta; 2010.

13. Profil Desa Busung Tahun 2017. 2017.

14. Pirmansyah P, Hilal TS, Munandar A. Hubungan antara Pengetahuan Masyarakat dan Peran Petugas Kesehatan dengan Sanitasi Jamban di Wilayah Kerja Puskesmas Batang Asai Kabupaten Sarolangun Tahun 2013. 2017;14(3).

15. Widyastutik O. Faktor Yang Berhubungan Dengan Kepemilikan Jamban Sehat Di Desa Malikian, Kalimantan Barat. 2017;13(1).

16. Novitry F, Agustin R. Determinan Kepemilikan Jamban Sehat di Desa Sukomulyo Martapura Palembang. 2017;2(2).

17. Notoatmodjo S. IImu kesehatan masyarakat: Prinsip-prinsip dasar. Jakarta: Rineka Cipta; 2012.

18. Novianti A. Hubungan Karakteristik Individu dengan Kepemilikan Jamban Keluarga di Desa Aek Goti Kecamatan Silangkitang Kabupaten Labuhanbatu Selatan Tahun 2017. 2017;

19. Dharma S, Santi DN. Faktor-faktor yang Berhubungan dengan Rendahnya Kepemilikan Jamban Keluarga dan Personal Hygiene dengan Kejadian Diare di Desa Sei Musam Kendit Kecamatan Bahorok Kabupatenlangkat Tahun 2014. 2015;3(3).

20. Putra GS, Selviana. Faktor-faktor yang berhubungan dengan kepemilikan jamban sehat di desa empakan kecamatan kayan hulu. J Kesehat Masy Khatulistiwa. 2017;4(3).

21. Maryunani A. Perilaku hidup bersih dan sehat (PHBS). Jakarta: Trans Info Media; 2013.

22. Joseph WBS, Warouw F. Faktor-faktor yang Berhubungan dengan tersedianya Jamban Keluarga Sehat di Desa Tompaso Dua Kecamatan Tomposa Barat Kabupaten Minahasa. 2018. 2018;7(1).

23. Fitri W, Putri G. Analisis Faktor yang Berhubungan dengan Rendahnya Kepemilikan Jamban di Desa Baru Semerah Kecamatan Sitinjau Laut 
Kabupaten Kerinci. J Kesehat Med Saintika. 2016;7(1):1-8.

24. Saliani H, Pinontoan OR, Posangi J, Universitas $P$, Ratulangi $S$. Faktorfaktor yang berhubungan dengan praktek buang air besar masyarakat di desa garuga kecamatan mantoh kabupaten banggai provinsi sulawesi tengah. 2016;1-20. 